\title{
云南木兰科植物物种资源及其种质库的研究*
}

\author{
李达孝 ${ }^{11}$ \\ (云南省林业科学院, 昆明 650204) \\ 杨绍诚 ${ }^{21}$ \\ (云南省文山州林业局，文山 663000) \\ 税希特 ${ }^{3)}$ \\ (云南省西畴县香坪山林场，西畴 663500)
}

\begin{abstract}
摘 要 $1980 \sim 1993$ 年期间, 在对云南省木兰科植物调查中, 发现云南省有木兰科植物 11 属 120 余种 并较集中地分布于滇东南, 滇西南和滇西北地区。为了保存、发展和利用木兰科植物资源，建立了三个 种质库基地，在 $24 \mathrm{hm}^{2}$ 面积内，共保存 10 属 129 种, 初步建立起木兰科种质库网络。
\end{abstract}

关键词 物种多样性, 木兰科植物, 种质库基地

Studies on the resources and gene pool bases of the Magnoliaceous plants in Yunnan Province/Li Daxiao ,Yang Shaochen, Shui Xite//CHINESE BIODIVERSITY. — 1995 3(4) $195 \sim 200$

The Magnoliaceous plants in Yunnan had been investigated during the last 14 years. Magnoliaceae consists of 11 genera and over 120 species in Yunnan Province, distributed primarily in three regions : southeastern Yunnan , southwestern Yunnan and northwestern Yunnan. Three gene pool bases covered an erea of $24 \mathrm{hm}^{2}$ have been established in Kunming, Wenshan and Xichou respectively and introduced 10 genera and 129 species to form gene pool networks for conservation, development and utilization of the magnoliaceous plants.

Author's address 1) Yunnan Academy of Forest Sciences , Kunming 650204

2 ) The Forest Bureau of Wenshan Prefecture, Yunnan Province , 663000

3 ) Xiang pingshan Forest Farm of Xichou county , Yunnan Province 663500

Key words Species diversity, Magnoliaceous Plants, Gene pool bases

云南省位于我国西南部, 为低纬度地区。由于受新生代以来喜马拉雅造山运动的影响, 这里山 大坡陡谷深、气候类型复杂, 保存了许多古热带植物区系成分。木兰科植物 (Magnoliaceae) 就是古 热带植物区系的重要成分之一,为原始的被子植物类群 ${ }^{[1]}$ 。

自 1980 年起, 我们每年于木兰科植物的花期 ( $4 \sim 5$ 月) 和果期 ( $9 \sim 10$ 月), 在省内 50 多个地 区进行深入调查和采集种子，木兰科植物的自然分布和调查样点见图 1 。

\section{1 木兰科植物的物种资源}

木兰科植物全世界共有 15 属, 云南省则分布 11 属。历时 14 年, 我们调查了云南省全境, 先后 与中国科学院华南植物研究所、昆明植物研究所和中山大学的有关科研人员发表了 24 个云南木兰 


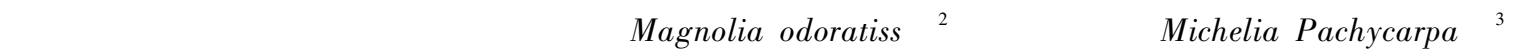
鼠刺含笑 $(M . \text { iteophylla })^{[4]}$ 、西畴含笑 $(M \text {. Coriacea })^{[5]}$ 、马关含笑 $(M . \text { opipara })^{[6]}$ 、畴阳含笑 $(M$. niti$d a)^{[5]}$, 卵果木莲 (Manglietia ovoldea $)^{[6]}$ 和壳叶木莲 $(\text { M. lucida })^{[7]}$ 等。

云南的木兰科植物常零星生长在原始森林内, 尤以海拔 $1300 \sim 1700 \mathrm{~m}$ 的山地常绿阔叶林和山 地沟谷雨林中分布最多。根据它们分布地相对较集中和种类分布的丰富程度、划分为三个主要自 然分布区(图1)。

滇东南分布区: 主要指北纬 $22 \sim 24^{\circ}$ 、东经 $102 \sim 106^{\circ}$ 的西畴、马关、麻栗坡、广南、金平、绿春和 屏边等县。该区海拔 $600 \sim 2250 \mathrm{~m}$, 年均气温为 $12 \sim 23.1{ }^{\circ} \mathrm{C}, \geqslant 10{ }^{\circ} \mathrm{C}$ 积温为 $4500 \sim 7500{ }^{\circ} \mathrm{C}$, 极端 最高气温为 $33 \sim 38{ }^{\circ} \mathrm{C}$ 极端最低气温为 $-0.4 \sim-0.7{ }^{\circ} \mathrm{C}$, 年降雨量在 $1007 \sim 1318 \mathrm{~mm}$ 之间, 年蒸 发量为 $1438 \sim 1500 \mathrm{~mm}$, 年平均相对湿度约 $80 \%$, 为南亚热带东南季风湿润气候。土壤有暗棕壤、 黄壤、黄棕壤和红壤四个类型。该分布区有木兰科植物 9 属、90 余种, 是该科植物在云南分布最集 中的地区，约占全省种数的 $60 \%$ 。常见有华盖木 (Manglietiastrum sinicum) 、云南拟单性木兰 (Parakmeria yunnanensis)、香木莲 ( $M$. aromatica) 和我鸟掌楸 (Liriodendron chinense)。它们与杪椤 ( $A l$ sophila spinulosa)、云南金钱械 (Dipteronia dyeriana)、马蛋果 (Gynocardia odorata)、云南七叶树 (Aesculus wangii)、喙核桃 (Annamocarya sinensis)、木瓜红 (Rehderodendron macrocarpum)、香樟 (Cinnamomum comphora $)$ 和云南樟 (C. glanduliferum) 等组成亚热带常绿湿润阔叶林。以城子山为例, 在面积 约 $4 \mathrm{hm}^{2}$ 的林地, 生长着云南拟单性木兰、马关木莲 ( $M$. maguania ) 和数株含笑属、木兰属树种; 在 大咕噜山面积约 $1 \mathrm{hm}^{2}$ 的林地, 有含笑属树种 2 种 20 余株、木莲属 1 种。它们树高 $13 \sim 20 \mathrm{~m}$ 、胸径 为 $70 \sim 130 \mathrm{~cm}$ 不等, 最大的一株高 $22 \mathrm{~m}$ 、胸径达 $220 \mathrm{~cm}$ 。

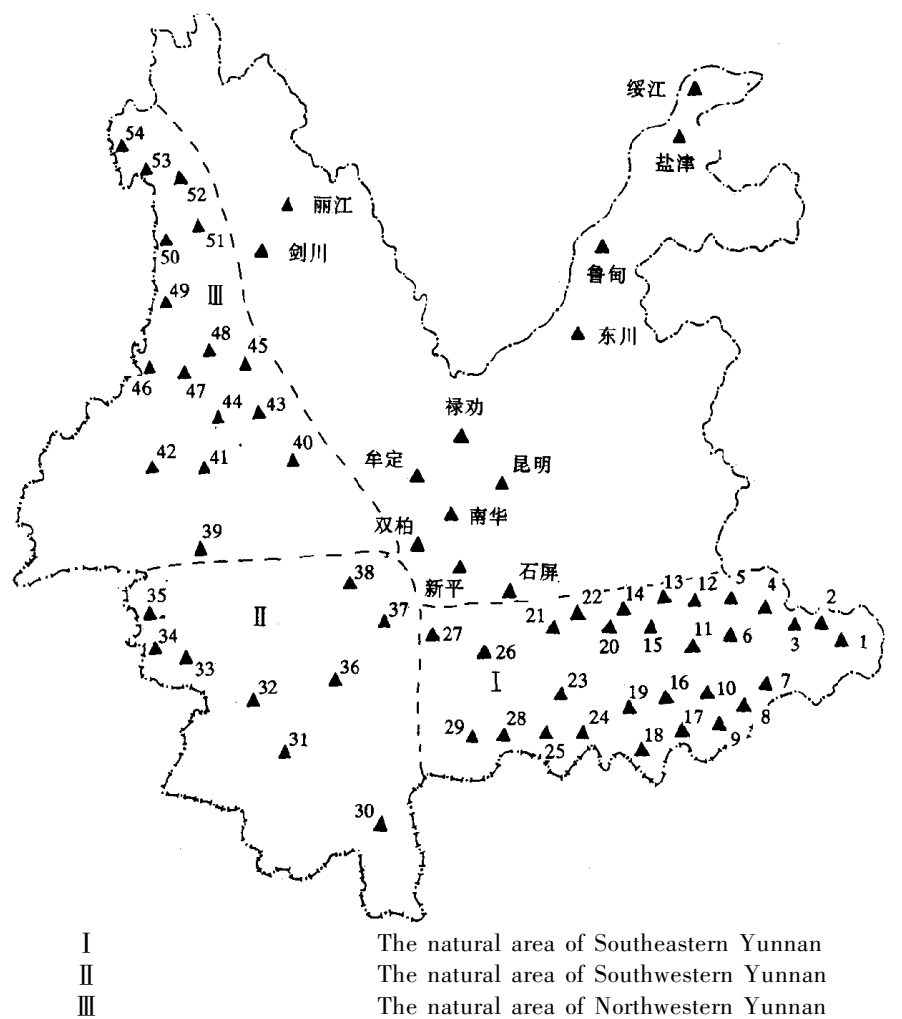


图注 Note

\begin{tabular}{|c|c|c|c|c|c|c|c|c|}
\hline $\begin{array}{c}\text { 号 } \\
\text { Number }\end{array}$ & $\begin{array}{l}\text { 地点 } \\
\text { Plot }\end{array}$ & $\begin{array}{l}\text { 海拔 ( m ) } \\
\text { Elevatlon }\end{array}$ & $\begin{array}{c}\text { 号 } \\
\text { Number }\end{array}$ & $\begin{array}{l}\text { 地点 } \\
\text { Plot }\end{array}$ & $\begin{array}{l}\text { 海拔 }(\mathrm{m}) \\
\text { Elevatlon }\end{array}$ & $\begin{array}{c}\text { 묵 } \\
\text { Number }\end{array}$ & $\begin{array}{c}\text { 地点 } \\
\text { Plot }\end{array}$ & $\begin{array}{l}\text { 海拔 }(\mathrm{m}) \\
\text { Elevatlon }\end{array}$ \\
\hline 1 & $\begin{array}{l}\text { 塘子 } \\
\text { Tangzl }\end{array}$ & 1300 & 19 & $\begin{array}{c}\text { 茅草坪 } \\
\text { Maocao Ping }\end{array}$ & 1200 & 37 & $\begin{array}{c}\text { 哀牢山 } \\
\text { Ailao sham }\end{array}$ & 1900 \\
\hline 2 & $\begin{array}{c}\text { 公莫山 } \\
\text { Gongmo Shan }\end{array}$ & 1400 & 20 & $\begin{array}{c}\text { 城子山 } \\
\text { Chengzi Shan }\end{array}$ & 1760 & 38 & $\begin{array}{c}\text { 大尖山 } \\
\text { Dajian Shan }\end{array}$ & $1600 / 2000$ \\
\hline 3 & $\begin{array}{c}\text { 里拱大山 } \\
\text { Ligong Dashan }\end{array}$ & 1310 & 21 & $\begin{array}{c}\text { 岔河山 } \\
\text { Chahe Shan }\end{array}$ & 1410 & 39 & $\begin{array}{c}\text { 小黑山 } \\
\text { Xiaohei Shan }\end{array}$ & $1600 / 2400$ \\
\hline 4 & $\begin{array}{c}\text { 大咕噜山 } \\
\text { Dagulu Shan }\end{array}$ & 1570 & 22 & $\begin{array}{c}\text { 油房坡 } \\
\text { Youfang Po }\end{array}$ & 1500 & 40 & $\begin{array}{c}\text { 观音山 } \\
\text { Guanyln Shan }\end{array}$ & 1820 \\
\hline 5 & $\begin{array}{c}\text { 花果大篝 } \\
\text { Huaguo Dagou }\end{array}$ & 1400 & 23 & $\begin{array}{c}\text { 古林篝 } \\
\text { Gulin Gou }\end{array}$ & 2100 & 41 & $\begin{array}{c}\text { 高黎贡山 } \\
\text { Gaoligong Shan }\end{array}$ & $1700 / 2250$ \\
\hline 6 & $\begin{array}{c}\text { 阿贵山 } \\
\text { Agul Shan }\end{array}$ & 1700 & 24 & $\begin{array}{c}\text { Ү曰大山 } \\
\text { Yakou Dashan }\end{array}$ & 1470 & 42 & $\begin{array}{c}\text { 山篝 } \\
\text { Shan Gou }\end{array}$ & 1900 \\
\hline 7 & $\begin{array}{c}\text { 铁厂山 } \\
\text { Tiechang Shan }\end{array}$ & 1330 & 25 & $\begin{array}{c}\text { 薄甲山 } \\
\text { Baojia Shan }\end{array}$ & 600 & 43 & $\begin{array}{c}\text { 宝台山 } \\
\text { Baotai Shan }\end{array}$ & $1900 / 2600$ \\
\hline 8 & $\begin{array}{c}\text { 金厂山 } \\
\text { Jinchang Shan }\end{array}$ & 1500 & 26 & $\begin{array}{c}\text { 大围山 } \\
\text { Dawei Shan }\end{array}$ & 1900 & 44 & $\begin{array}{c}\text { 志奔山 } \\
\text { Zhiben Shan }\end{array}$ & $2400 / 3100$ \\
\hline 9 & $\begin{array}{c}\text { 大锡山 } \\
\text { Daxi Shan }\end{array}$ & 1340 & 27 & $\begin{array}{c}\text { 黄连山 } \\
\text { Huanglian } \\
\text { Shan }\end{array}$ & 1900 & 45 & $\begin{array}{c}\text { 天池 } \\
\text { Tianchi }\end{array}$ & 2500 \\
\hline 10 & $\begin{array}{c}\text { 中寨山 } \\
\text { Zhongzhai Shan }\end{array}$ & 1950 & 28 & $\begin{array}{c}\text { 分水老林 } \\
\text { Fenshui Laolin }\end{array}$ & 1950 & 46 & $\begin{array}{c}\text { 片马大山 } \\
\text { Pianma Dashan }\end{array}$ & $1500 / 2000$ \\
\hline 11 & $\begin{array}{c}\text { 畴阳河 } \\
\text { Chouyang He }\end{array}$ & 1400 & 29 & $\begin{array}{c}\text { 闸门寨 } \\
\text { Zhamen Zhai }\end{array}$ & 1800 & 47 & $\begin{array}{l}\text { 沪水 } \\
\text { Lu Shui }\end{array}$ & 1800 \\
\hline 12 & $\begin{array}{c}\text { 黄龙山 } \\
\text { Huanglong Shan }\end{array}$ & 1150 & 30 & $\begin{array}{c}\text { 预脂 } \\
\text { Mengla }\end{array}$ & 300 & 48 & $\begin{array}{c}\text { 碧江 } \\
\text { Bi Jiang }\end{array}$ & 1900 \\
\hline 13 & $\begin{array}{c}\text { 青弯山 } \\
\text { Qingwan Shan }\end{array}$ & 1570 & 31 & $\begin{array}{c}\text { 预海 } \\
\text { Menghai }\end{array}$ & 1500 & 49 & $\begin{array}{c}\text { 俅江 } \\
\text { Qiu jiang }\end{array}$ & 2300 \\
\hline 14 & $\begin{array}{c}\text { 毛河湾 } \\
\text { Maohcwan }\end{array}$ & 1500 & 32 & $\begin{array}{c}\text { 澜沧 } \\
\text { Lancang }\end{array}$ & 1000 & 50 & $\begin{array}{c}\text { 古木篝 } \\
\text { Gumu Gou }\end{array}$ & 2500 \\
\hline 15 & $\begin{array}{c}\text { 文山老君山 } \\
\text { Wenshan Laojun } \\
\text { Shan }\end{array}$ & 2250 & 33 & $\begin{array}{c}\text { 预角大山 } \\
\text { Mengjiao Dashan }\end{array}$ & $1350 / 2000$ & 51 & $\begin{array}{c}\text { 上帕 } \\
\text { Shangpa }\end{array}$ & 2000 \\
\hline 16 & $\begin{array}{l}\text { 大栗树 } \\
\text { Dalishu }\end{array}$ & 1400 & 34 & $\begin{array}{c}\text { 班洪山 } \\
\text { Banhong Shan }\end{array}$ & 1900 & 52 & $\begin{array}{l}\text { 维西 } \\
\text { Weixi }\end{array}$ & 2300 \\
\hline 17 & $\begin{array}{c}\text { 大黑山 } \\
\text { Dahei Shan }\end{array}$ & 2100 & 35 & $\begin{array}{c}\text { 木莲花山 } \\
\text { Mulianhua Shan }\end{array}$ & 2080 & 53 & $\begin{array}{l}\text { 普拉河 } \\
\text { Pula He }\end{array}$ & 1600 \\
\hline 18 & $\begin{array}{c}\text { 老君山 } \\
\text { Laojun Shan }\end{array}$ & 1950 & 36 & $\begin{array}{c}\text { 大雪山 } \\
\text { Daxuc Shan }\end{array}$ & $2000 / 3100$ & 54 & $\begin{array}{c}\text { 独龙江 } \\
\text { Dulong Jiang }\end{array}$ & $1200 / 2800$ \\
\hline
\end{tabular}

滇西南分布区: 主要指北纬 $21 \sim 24^{\circ}$, 东经 $99 \sim 102^{\circ}$ 的临沦、沦源、镇康、景洪、预海和预腊等 县。该区海拔 $300 \sim 2400 \mathrm{~m}$, 年平均气温为 $21 \sim 23{ }^{\circ} \mathrm{C}$, 年降雨量在 $1800 \sim 2400 \mathrm{~mm}$ 之间, 年均相对 湿度为 $80 \%$, 属热带湿润气候。土壤为砖红壤和赤红壤。这里的木兰科植物有 6 属 30 余种。常 见的有思茅玉兰 (Magnolia henryi)、香子含笑 (Michelia hedyospernia) 和合果木 (Paramichelia 
baillonii)。它们与红椿 (Toona ciliata)、云南石梓 (Gmelina arborea)、云南翅子树 (Pterospermum yunnanense)、五桠果叶木姜子 (Litsea dilleniifolia) 和香龙眼 (Pometia tomentose) 组成季雨林 ( 又 称沟谷雨林) 和季风常绿阔叶林。

滇西北分布区: 主要指北纬 $25 \sim 29^{\circ}$, 东经 $98 \sim 100^{\circ}$ 的腾冲、云龙、沪水、福贡、贡山和维西等 县。该区海拔为 $1750 \sim 3500 \mathrm{~m}$, 年均温为 $10 \sim 15{ }^{\circ} \mathrm{C}$, 最高气温为 $30 \sim 37{ }^{\circ} \mathrm{C}$, 最低温为 $-4 \sim-12$ ${ }^{\circ} \mathrm{C}$, 年降雨量为 $1185 \sim 1439 \mathrm{~mm}$, 年均相对湿度为 $76 \sim 82 \%$, 属亚热带高山温凉气候。土壤为黄棕 壤、黄红壤。这里的木兰科植物有 5 属 40 余种, 常见的有滇藏木兰 (Magnolia campbelii)、长喙厚 朴 (M. rostrata)、西康玉兰 (M. wilsonii) 和线叶含笑 (Michelia velutina)。它们与秃杉 (Taiwania flousiana)、丽江方杉 (Picea likiangensis)、高山体 (Betula delavayi) 和模楠( Phoebe nanmu) 等组成 常绿叶阔叶混交林。

除上述自然分布地区外，木兰科植物在村庄旁、寺庙和风景区也常见到。这些地方，由于人为 保护，它们高大挺拔，繁茂美观，花大色香，不少种类被列为名木古树。如树高 $40 \mathrm{~m}$, 胸径 $120 \mathrm{~cm}$ 的华盖木; 树高 $35 \mathrm{~m}$,胸径 $200 \mathrm{~cm}$ 的云南拟单性木兰;树高 $35 \mathrm{~m}$, 胸径 $240 \mathrm{~cm}$ 的线叶含笑 (Michelia vetina) 和树高 $20 \mathrm{~m}$,胸径 $140 \mathrm{~cm}$ 的麻栗坡含笑 (M. chartacea) 等。

\section{2 建立木兰科植物种质库基地}

依据野外调查获得的有关木兰科植物地理分布、生态环境和生物学特性资料,云南省自然分布 的木兰科植物有 11 属 120 多种, 并形成了三个自然分布区, 它不愧是中国木兰科植物的现代分布 中心 (图 1)。但木兰科植物自然繁衍、更新的能力很弱, 如华盖木 4 月开花, 10 月种子成熟, 开花 结实年复一年, 但在其附近却找不到一株实生苗, 经过采摘果实进一步观察, 每个聚合果其果皮为 【【木质结构, 很难自然开裂散出种子, 因此每个果内的 $5 \sim 10$ 粒种子霉烂掉。我们对采回来的 100 余种植物的种子进行检测, 多数种子均具有休眠期, 并且种子不宜曝晒和干藏, 需采取必须的 人工措施，打破或缩短休眠期，即使如此，种子的发芽率仍然较低。如华盖木、云南拟单性木兰和大 果木

表 1 种质库基地的自然条件

Table 1 The natural canditions of three gene pool bases.

\begin{tabular}{|c|c|c|c|}
\hline $\begin{array}{l}\text { 种质库基地 } \\
\text { Gene pool bases }\end{array}$ & $\begin{array}{c}\text { 昆明树木园 } \\
\text { Kunming } \\
\text { Arboretun }\end{array}$ & $\begin{array}{c}\text { 香坪山树木园 } \\
\text { Xiangpingshan } \\
\text { Arboretum }\end{array}$ & $\begin{array}{c}\text { 文山木兰园 } \\
\text { wengshan } \\
\text { Magnoliacean } \\
\text { garden } \\
\end{array}$ \\
\hline 位置 Site & $\begin{array}{l}\mathrm{N} 25^{\circ} 07^{\prime} \\
\mathrm{E} 102^{\circ} 45^{\prime}\end{array}$ & $\begin{array}{l}\mathrm{N} 23^{\circ} 23^{\prime} \\
\mathrm{E} 104^{\circ} 40^{\prime}\end{array}$ & $\begin{array}{l}\mathrm{N} 23^{\circ} 23^{\prime} \\
\mathrm{E} 104^{\circ}\end{array}$ \\
\hline 海拔 $(\mathrm{m}) \quad$ Elevation & 1970 & 1370 & 1246 \\
\hline 年平均气温 $\left({ }^{\circ} \mathrm{C}\right)$ Annual mean temperature & 14.7 & 16.3 & 16.0 \\
\hline 相对湿度 (\%) Relative humidity & 73 & 83 & 77 \\
\hline $\begin{array}{l}\text { 极端最高气温 }\left({ }^{\circ} \mathrm{C}\right) \quad \begin{array}{l}\text { Absolute maximum tem- } \\
\text { perature }\end{array}\end{array}$ & 31.5 & 31.0 & 34.4 \\
\hline $\begin{array}{l}\text { 极端最低气温 }\left({ }^{\circ} \mathrm{C}\right) \\
\begin{array}{l}\text { Absolute minimum tem- } \\
\text { perature }\end{array}\end{array}$ & -7.6 & -0.4 & -3.0 \\
\hline Annual precipitation & 985.1 & 1276 & $1000 \sim 1200$ \\
\hline Annual vaporation & 1512.7 & 1198.5 & 1404.6 \\
\hline $\begin{array}{l}\text { 土 壤 Soil } \\
\mathrm{pH} \text { 值 }\end{array}$ & $\begin{array}{c}\text { 红壤 Red soil } \\
5.0 \sim 5.5\end{array}$ & $\begin{array}{c}\text { 黄壤 Yellow soil } \\
7.5\end{array}$ & $\begin{array}{c}\text { 黄壤 Yellow soil } \\
8.5\end{array}$ \\
\hline
\end{tabular}


莲的发芽势分别为 62\%、46\% 和 53\%（1989 年种子发芽试验）,成苗率和移栽成活率也还存在尚需 解决的技术问题。这些事实反映出建立种质库的迫切性和必要性。特别是木兰科植物的极高园林 观赏价值，使其成为城镇园林建设不可多得的好树种，应大力发挥它们对人类的生态效益和社会效 益。为此, 我们选择昆明树木园、西畴县香坪山树木园和文山州木兰园作为木兰科植物种质库的基 地，其自然条件见表 1 。

1991 年, 我们选择同龄、生长状况基本一致的 5 个树种,同期分别栽种到三个种质库基地, 比 较它们在一年中树高生长的情况 (图 2)。

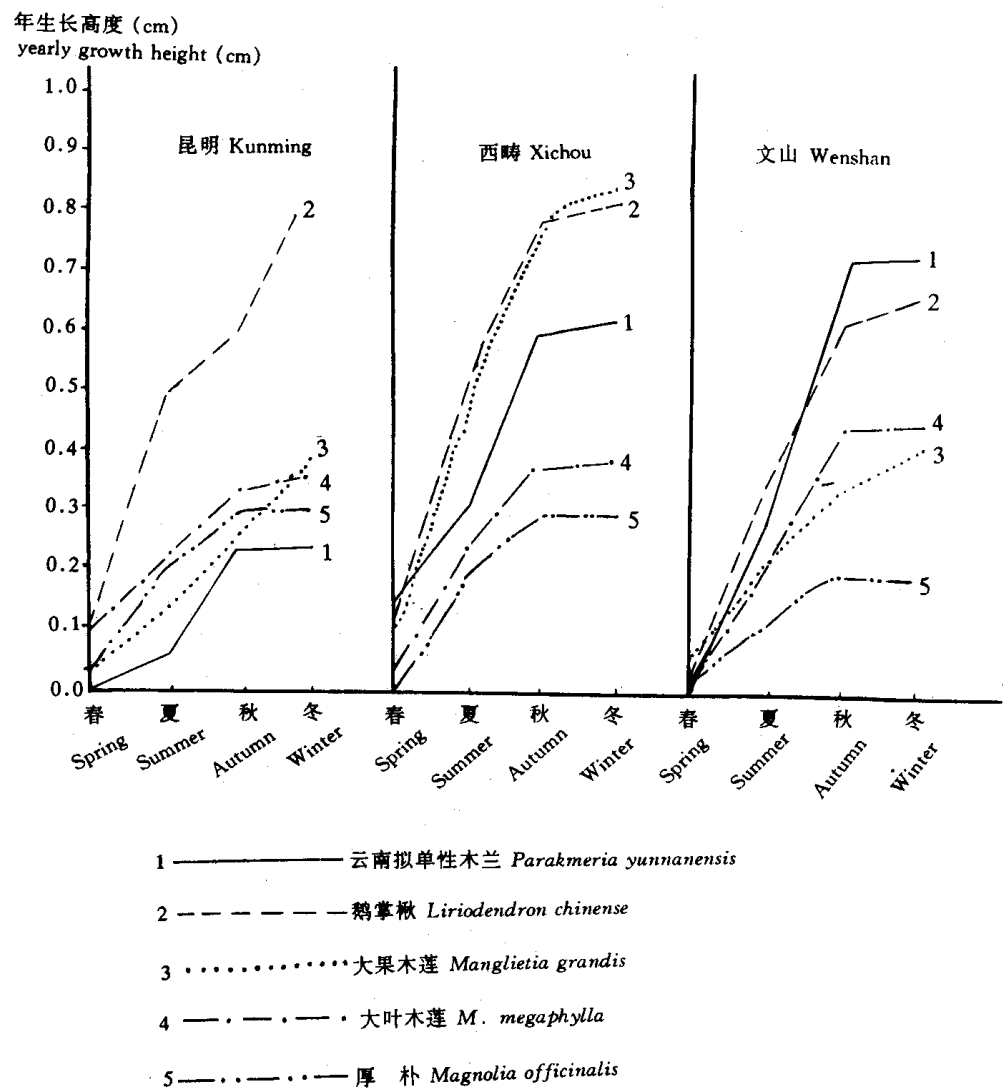

图 25 个同龄树种在不同生境中年生长量的比较

Fig. 2 The comparison of year growth quantity of 5 same age species in different habitant.

从 5 个树种在不同生境里其生长量所表现出的不同,反映出它们存在着遗传多样性方面的差 异, 其差异的原因和实质将是有待于深入研究的, 这正是我们要建立种质库网络的原因之一。

$$
3 \text { 讨 论 }
$$

3.1 通过 14 年的野外调查研究及对周围邻近省份木兰科植物的考察和资料收集,云南省是我国 木兰科植物现代分布中心已置信无疑，它们在古热带植物区系中占有重要的地位。但是同一种或 同属的木兰科植物能否在同纬度、生境大致相似的地区分布更相对地集中些, 将有待于深入研究。 
植物种质资源保存及开发利用提供了广阔前景。将移地保存和就地保护紧密结合, 形成一种保护 物种及遗传多样性网络的新格局, 对了解物种遗传的稳定性和变异性具有重要的意义。

3.3 引种木兰科植物, 气候条件是重要的制约因素。昆明冬季曾出现极端低温 $-7{ }^{\circ} \mathrm{C}, 3$ 月又出 现反春寒低温 $-0.2 \sim 2.3^{\circ} \mathrm{C}$, 冬春干旱达到蒸发量为降雨量的 8 倍, 因此应注意防寒和灌溉。其 它地区引种时,一定要借鉴这一经验。

3.4 从调查物种的自然分布、生态环境和生物学特性入手, 并亲自采种、育苗和栽种, 对查清资源 数量、全面掌握其生长习性, 因地制宜地选用最佳栽培技术, 是一条值得沿用和推广的研究路线, 它 将为深入研究和应用某一类植物提供科学依据和实践经验。

3.5 我们认为昆明、文山和西畴的木兰科植物种质库应由国家或地方政府拨款, 使之成为深入研 究木兰科植物系统发育和演化及资源开发利用的基地。

\section{参 考 文 献}

1 刘玉壸，木兰科分类系统的初步研究. 植物学分类学报, 1984 22 (2) 889 109

2 刘玉壶, 周仁章, 广东、云南木兰科一新种. 植物研究, 1986 ,6 (2) : 139 141

3 刘玉壶, 周仁章, 云南含笑属新植物. 植物研究, 1987 ,7 (1) $85 \sim 86$

4 刘玉壶, 吴容芬, 中国含笑属新植物. 云南植物研究, 1988, 10 (3) 335 342

5 陈宝樑,云南含笑属四新种. 中山大学学报 , 1987 3 :86 91

6 陈宝樑,云南木兰科植物. 中山大学学报, 1988, 1:107 112

7 陈宝樑、杨绍诚, 云南木兰科新植物. 中山大学学报, 1988 3 $94 \sim 99$ 